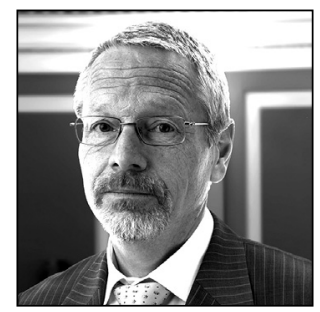

Kåre Lilleholt $^{* 1}$

Professor

University of Oslo

\title{
Norway: Non-secured Instant Loans to Consumers"
}

\section{Introduction}

This article deals with the Norwegian legal framework concerning non-secured 'instant' loans to consumers. The loans are 'instant' because the procedure of applying for and granting them is meant to be fast and uncomplicated, often so as to make the money available the same day as the loan is applied for, or just a few days later. There is no requirement of a mortgage, surety, or other security right. The loan is not granted for a specific purpose. The business idea is obviously to offer access to cash rather informally and on short notice; the term 'easy loan' is often used in advertising on the Internet. In Norwegian, such loans are often called forbrukslån, literally 'loans for consumption'.

Non-secured instant loans to consumers are offered by several actors in Norway. The most important lenders seem to be banks, providing loans either directly or through intermediaries. Those offering credit services to Norwegian customers (whether banks, other financial institutions, or even businesses established abroad) are subject to public licence and supervision requirements (see Section 2). In practice, there are likely to be few cases of credit granted to consumers living in Norway by institutions not established in Norway and not offering their services here (the consumer thus having actively contacted the lender abroad); no statistical information is available, however.

Advertising indicates that the following example is representative. ${ }^{*} 3$ The consumer may borrow between NOK 5,000 and NOK 400,000 (EUR 625-50,000). The effective annual percentage rate (APR) varies between 9.59 and 21.24 per cent and the initial rate depends on the borrower's 'financial situation'. The amortisation period is, at maximum, 15 years. The borrower may repay the loan at any time at no extra cost, as the interest rate is variable. The borrower must be a Norwegian citizen, have an income, and have no active debt collection actions against him.

There is one provider of even smaller instant loans, Folkia AS. ${ }^{*}$ For such loans the relative costs are higher; a loan of NOK 1000 (EUR 125) for one month, for example, has a staggering APR of 9242 per cent, due not least to NOK 350 (EUR 44) of set-up charges. Folkia AS is a rather small actor in the Norwegian credit market but the business concept has naturally drawn some public attention.

Alternatives to the loans described above are overdraft facilities and credit cards, both of which are rather common. Credit costs are regularly quite high for these alternatives as well.

1 The author would like to thank Katherine Llorca for her text editing.

2 The research leading to these results has received funding from the Norway Financial Mechanism 2009-2014 under project contract No. EMP205.

3 From Bank Norwegian AS (www.banknorwegian.no, most recently accessed on 7 February 2014). For other examples, see DnB (www.dnb.no, most recently accessed on 7 February 2014); Santander Consumer Bank (www.santander.no, most recently accessed on 7.22014); GE Money Bank Norge (www.gemoney.no, most recently accessed on 7.2.2014).

4 See folkia.no (most recently accessed on 7.2.2014). 
For the sake of completeness and in order to paint a clearer picture of the market, it should be mentioned that credit for unspecified purposes may also easily be obtained in the form of credit secured under a previously-established mortgage-typically a mortgage on the consumer's home-in the form of either a draft facility or a fixed loan. This requires a little more paperwork but is usually less expensive than the loans just described. Consumer mortgages are mostly provided by banks, and a new loan secured under the mortgage will typically be provided by the same bank. A loan from another bank, secured by a second mortgage, can serve the same purposes.

Household debt is high in Norway. Home loans and an expensive property market are the main reasons for this, and 'loans for consumption' make up just a small proportion (less than three per cent) of total household debt. ${ }^{*}$ On the other hand, such loans are much more commonly the object of debt settlement and debt collection cases against consumers (see Section 3, below).

\section{Licensing, supervision, and marketing}

\subsection{Licensing and supervision}

Providing credit and acting as an intermediary for the provision of credit are examples of 'financial services', and financial services may only be offered by-among others-banks and finance companies licensed under the Financial Institutions Act. ${ }^{* 6}$ Norwegian businesses of this kind are subject to supervision by the Financial Supervisory Authority of Norway. ${ }^{*} 7$

Norway is a party to the Agreement on the European Economic Area (EEA). This agreement includes rules on the four freedoms corresponding to the rules of the treaties of the European Union, and much of the secondary EU legislation, including legislation on financial markets, has been made binding on non-EU members of the EEA. As a result, credit institutions licensed and supervised in another EEA member state are allowed to offer financial services in Norway. ${ }^{*}$ Branches of such credit institutions need a licence under Norwegian law. ${ }^{*} 9$ The provision of financial services by foreign credit institutions (cross-border services) is subject to supervision by the Financial Supervisory Authority of Norway and so are the activities of Norwegian branches of foreign credit institutions. ${ }^{* 10}$

These rules on licence requirements and on supervision are stricter in Norway than in many other countries. Licence requirements and supervision probably contribute considerably to compliance with consumer protection rules, as the loss of one's licence-or a warning that it may be lost-is a more efficient enforcement tool than available civil law remedies.

There are general rules in the Financial Institutions Act and related regulations concerning the organisation, capital, etc. of institutions offering financial services.

\subsection{Requirements regarding marketing and conduct of business}

Chapter 3 of the Financial Contracts Act deals with credit contracts. ${ }^{*} 11$ The scope of the chapter is somewhat wider than the title indicates. Some of the rules concern the contractual relationship between lender and borrower, addressing the conclusion and validity of the contract, mandatory rules on the content of the contract, etc. Other rules primarily concern the marketing of credit contracts and the lender's information duties. The latter are mainly rules of conduct, and violation of these rules may ultimately have consequences for the lender's licence to act as a financial institution. In addition, the Consumer Ombudsman and the Market Council are authorised to take measures against unfair commercial practices and unfair contract

\footnotetext{
Finanstilsynet, Finansielt utsyn 2014 ['Risk Outlook 2014: The Financial Market in Norway'], Oslo 2014, pp. 24-25.

6 Lov 40/1988 om finansieringsvirksomhet og finansinstitusjoner (Financial Institutions Act), Sections 1-2 and 1-4. Some narrow exceptions for credit sales and for occasional credit are of little interest and will not be dealt with here.

Lov 7. desember $1956 \mathrm{nr} .1$ om tilsynet med finansinstitusjoner mv. (Financial Supervision Act), Section 1.

Financial Institutions Act, Section 1-4, No. 4.

Financial Institutions Act, Section 3-3.

Administrative regulation 717/1994, Section 9 and administrative regulation 326/1994, Section 11.

Lov 46/1999 om finansavtaler og finansoppdrag (Financial Contracts Act).
} 
terms. The basis of this control can be found in both the Financial Contracts Act and the Marketing Act. ${ }^{* 12}$ Some of the rules have a double edge and a violation may have consequences both in contract law and in public law; for example, a breach of information duties may both affect the contractual relationship and at the same time lead to reactions from the Financial Supervisory Authority or the Consumer Ombudsman and the Market Council. In addition to the rules in the Financial Contracts Act (see below), general rules on marketing apply, such as restrictions on sales or marketing by telephone etc.

Directive 2008/48/EC, on consumer credit agreements, is transposed through Chapter 3 of the Financial Contracts Act. The rules corresponding to the rules of the Directive on pre-contractual information and on information that must be included in the credit contract will not be dealt with in detail here.

Marketing of credit contracts must include information on the borrowing rate, the total amount of credit, APR, etc., specified by means of a representative example. ${ }^{*}{ }^{13} \mathrm{~A}$ glance at some Web pages indicates that lenders generally comply with these requirements. Some of the Web pages even include loan calculators, illustrating how costs vary with the loan amount and the credit period.

More specific information on the credit contract in question must be given 'in good time' and before the consumer is bound by the contract. ${ }^{* 14}$ To give such information 'in good time' when the business concept is instant credit may seem like a contradiction in terms. Most likely, the information is given by e-mail, so the consumer must decide for himself how much time is needed to study it.

The lender must also provide 'adequate explanations', enabling the consumer to 'assess whether the proposed credit agreement is adapted to his needs and to his financial situation'. ${ }^{*} 5$ At least for the smallest loans, it seems more or less impossible to offer individual explanations of this kind; the administrative costs would be too high. Directive 2008/48 (Art. 5(6)) allows Member States to adapt this rule to the circumstances, but no such adaptations have been made in Norway. Regarding this rule, compliance may turn out to be questionable for providers of the loans here discussed.

The lender must assess the consumer's creditworthiness, if necessary by consulting a relevant database. ${ }^{*} 16$ To date (February 2014), no relevant database or register (positive or negative) has been established in Norway. A proposal for legislation on a consumer debt register was submitted to Parliament in September 2013 but was subsequently withdrawn by the new government in November 2013, before it had been discussed at all in the Parliament; the new government wanted to re-evaluate 'some elements of the proposal. ${ }^{\text {'17 }}$

Today, assessment of a consumer's creditworthiness is based on an enquiry submitted to a credit reference agency, in addition to confirmation of employment. Credit reference enquiries can be carried out online; the consumer receives a paper copy of the answer a few days later. The agency will often report previous income and property, based on public information from tax authorities, the Land Registry, etc. and, where necessary, recent debt collection actions against the consumer. Credit reference agencies are private businesses and need a licence from the Norwegian Data Protection Agency. Rules of conduct are imposed by the licence. In February 2014, nine licences were active. ${ }^{*} 8$

Under the Financial Contracts Act, Section 47, the lender has a duty to warn the consumer if the lender could not have been unaware of the fact that the consumer, because of his financial situation or other circumstances, should seriously consider foregoing the loan. The warning (literally 'dissuasion') must be given in writing and, if possible, also orally if the contract has not yet been concluded. A breach of the lender's duty to warn may lead to an adjustment of the consumer's obligations under the contract if that is deemed reasonable by a court.

The duty to warn the consumer goes further than the information duties under Directive 2008/48. The Norwegian government held that the lender's duty to warn was based on general principles of loyalty in contractual relationships and thus was not contrary to total harmonisation as envisaged by Directive 2008/48. The government also referred to remarks in the preamble to the directive (paragraph 26 in the

12 Lov 2/2009 om kontroll med markedsforing og avtalevilkår mv. (Marketing Act); this Act is also a transposition of Directive 2005/29/EC, on unfair commercial practices.

13 Directive 2008/48, Art. 4; Financial Contracts Act, Section 46.

14 Directive 2008/48, Art. 5; Financial Contracts Act, Section 46 a.

15 Directive 2008/48, Art. 5(6); Financial Contracts Act, Section 46 c.

16 Directive 2008/48, Art. 6; Financial Contracts Act, Section 46 b.

17 Prop. 195 L (2012-2013), Endringer i tinglysingsloven mv. (registrering av gjeld) (the Government's proposal to the Parliament); Meld. St. 17 (2013-2014), Tilbaketrekning av Prop. 195 L (2012-2013), Endringer itinglysingsloven mv. (registrering av gjeld) (the Government's white paper to the Parliament).

18 See www.datatilsynet.no (most recently accessed on 12.4.2014). 
final version) on responsible lending. ${ }^{*}{ }^{*}$ Responsible lending duties did not become incorporated into the final version of the directive.

Adjustment of the consumer's obligations due to lack of warning under the provision in Section 47 of the Financial Contracts Act has not yet been invoked successfully before the Norwegian Supreme Court (and, in total, it has been invoked in only three cases). ${ }^{{ }^{20}}$ The consumer's obligations have been adjusted in a few cases by the Financial Complaints Panel (Finansklagenemnda), but the consumer has lost in most cases. ${ }^{{ }^{21}}$ So far, it seems fair to say that the duty to warn the consumer is a frail consumer protection instrument.

\section{Consumer insolvency}

Legislation concerning debt settlement for private individuals was introduced in Norway in $1992 .{ }^{* 22}$ This legislation aims to give persons with serious debt problems the possibility to regain control over their financial situation.

Under the Debt Settlement Act, a debtor may apply to the local Enforcement Officer for the opening of a protected period of negotiations with creditors. The Enforcement Officer has an important role in the civil enforcement system, and his decisions may be appealed to the local court of first instance. Negotiations are opened if the criterion of serious debt problems is met, the applicant is willing to co-operate, and debt settlement would not be considered 'offensive' for the reasons specified in the Act. There is a debt moratorium during the negotiation period.

Debt settlement is either voluntary or compulsory. The settlement is voluntary if the debtor's proposal is not opposed by any creditor. If negotiations for a voluntary settlement fail, a compulsory settlement may be decided on by the court. The proportion of voluntary settlements has increased and now amounts to around 80 per cent of all debt settlements. ${ }^{*} 3$

To obtain a settlement, the debtor must-as a rule-sell assets that are not needed for a minimum standard of life. Further, the debtor must agree to use any income exceeding a fixed minimum as a dividend to his creditors for a period of normally five years. If the settlement is fulfilled, the debtor is then discharged (with some exceptions for secured loans, etc.).

Today, it is accepted that debt settlement may be decided on without any dividend at all for the creditors. Such 'zero settlements' now amount to around 60 per cent of the total number of settlements. ${ }^{{ }_{2} 4}$ In these cases too, the settlement period is normally five years. The high number of 'zero settlements' indicates that the debt settlement regime is particularly important for persons without normal employment.

The total number of settlements of debt is not high-68 negotiations opened per 100,000 inhabitants of Norway in 2011. The total number of debt settlements peaked in 2011 and has not decreased much in 2012 and 2013. In Oslo, the number has increased in the same period. ${ }^{* 25}$

From a comparative perspective ${ }^{*} 26$, the relatively high number of voluntary settlements and 'zero settlements' is quite interesting.

It seems that 'loans for consumption' account for larger share of the total debt in typical debt settlements than they used to, some years ago. ${ }^{* 27}$ Of the total number of debt collection cases against consumers, 13 per cent are related to loans for consumption. ${ }^{*} 8$

19 Ot.prp. nr. 22 (2007-2008), p. 40 (the Government's proposal to the Parliament).

20 Norsk Retstidende (Rt.) 2003, p. 1252; Rt. 2004, p. 156; Rt. 2013, p. 388.

21 See, for example, FINKN-2011-577 and FINKN-2011-274.

22 Lov 99/1992 om frivillig og tvungen gjeldsordning for privatpersoner (Debt Settlement Act).

23 Statistics made available by the Ministry of Children, Equality and Social Inclusion (February 2014). See also C. Poppe, R. Lavik, Hvorfor øker antall gjeldsordningssaker i Oslo? ['Why is the number of debt settlement cases increasing in Oslo?']. Oslo: Statens institutt for forbruksforskning 2013, pp. 32-33.

24 Statistics made available by the Ministry of Children, Equality and Social Inclusion (February 2014).

25 See C. Poppe, R. Lavik (Note 22), pp. 9-13. Statistics made available by the Ministry of Children, Equality and Social Inclusion (February 2014).

26 For international comparisons, see, for example, J. Spooner. 'Fresh start or stalemate? European consumer insolvency law reform and the politics of household debt. - European Review of Private Law 21 (2013)/3, pp. 747-794. Insolvency and Creditor/Debtor Regimes Task Force (World Bank, Working Group on the Treatment of the Insolvency of Natural Persons), 2013.

27 See C. Poppe, R. Lavik (Note 22), pp. 51-56.

28 Prop. 195 L (2012-2013), 21. 
Municipalities have a duty to assist-'as far as possible'-persons trying to obtain debt settlements under the Debt Settlement Act, and the municipalities also have general duties to give advice under legislation on social services. ${ }^{* 29}$ The availability of such assistance and advice seems to vary quite a lot from one area to another.

A survey done in January 2014 showed that 'loans for consumption' led to 12.5 percent of the debt collection cases (compared to two per cent for home loans). Small claims from mail order purchases, parking fines, etc. were the basis of the majority of debt collection cases. ${ }^{*} 30$

\section{Contract law}

Credit contracts are regulated in the Financial Contracts Act in addition to general contract law-legislated and non-legislated.

A credit contract is not binding on the consumer unless it is 'in writing', but writing includes electronic means of concluding a contract as long as the content of the contract is available to the consumer at the time of conclusion and the conclusion of the contract is made authentic in a reliable manner. ${ }^{*}{ }^{*}$ The banks have developed a solution for electronic signatures, a solution that is applied both by banks and by other businesses offering the loans dealt with in this article. In this way, a credit contract can be validly concluded on the Internet.

Unfair marketing practices or breach of pre-contractual information duties does not automatically affect the contractual relationship but may, depending on the circumstances, lead to revision of the contract based on general contract law. Terms not included in the written contract are not binding on the consumer unless the lender proves that the term was accepted by the consumer. ${ }^{*} 32$

It was explained under Subsection 2.2 above that breach of the duty to warn a consumer (where necessary) about the risks of taking out a loan may lead to adjustment of the consumer's obligations under the contract.

The consumer has a right to withdraw from the credit contract within 14 calendar days of signing or of receiving relevant information concerning the right of withdrawal, whichever is later. ${ }^{*} 33$ If the consumer exercises his right to withdraw, he must repay the money received, with interest (at the nominal interest rate). The lender is not entitled to any other compensation except possible charges by a public administrative body. These rules apply even to small loans, whereas Directive 2008/48 applies only to credit contracts involving a total amount of credit of at least EUR 200. ${ }^{*}{ }^{4}$ For the very short-term credit contracts, the right of withdrawal seems to offer the 'cunning' consumer an easy way out of paying set-up fees.

There are no provisions in the Financial Contracts Act on the maximum credit costs allowed. A provision in the Price Measures Act prohibiting 'unreasonable' prices is generally thought to have little importance in today's liberal market economy. ${ }^{*} 35$ The most relevant provision to apply in an assessment of potentially excessive credit costs is Section 36 of the Formation of Contracts Act, the so-called general clause, common to all the Nordic countries. ${ }^{*} 6$ This provision, with some small additions regarding non-negotiated terms, has been regarded as sufficient transposition of Directive 93/13/EEC, on unfair contract terms in contracts with consumers.

The general clause has almost never been applied by Norwegian courts so as to adjust an agreed price or remuneration, at least not because the price was regarded as too high (in some cases regarding ground leases, the rent has been adjusted upwards in order to compensate for inflation). ${ }^{*} 37$ This is also in line with

29 Debt Settlement Act, Section 1-5; Lov 131/2009 om sosiale tjenester i arbeids-og velferdsforvaltningen (Social Services Act), Section 17.

30 Finanstilsynet, Finansielt utsyn 2014 (see Note 4), p. 25.

31 Financial Contracts Act, Sections 8 and 48.

32 Financial Contracts Act, Section 48(4).

33 Financial Contracts Act, Section 51 b; cf. Directive 2008/48, Art. 14.

34 See Directive 2008/48, Art. 2(2)(c); cf. Preamble, para. 10.

35 Lov 66/1993 om pristiltak (Price Measures Act), Section 2. See also the Supreme Court judgment in Rt. 1996, p. 407.

36 Lov 31. mai $1918 \mathrm{nr} .4$ om avslutning av avtaler, om fuldmagt og om ugyldige viljeserklæringer (Formation of Contracts Act), Section 36.

37 K. Lilleholt. Application of general principles in private law in the Nordic countries. - Juridica International 2013, pp. $12-19$. 
Directive 93/13, Art. 4, which excludes from the unfairness test any balancing between the 'main subject matter' and the price. ${ }^{*} 38$ Adjustment of the price is not entirely excluded under the general clause, but it should not normally be done unless there are elements of misleading information, fraud, or unfair exploitation. ${ }^{*} 39$

In private law, there are no rules dealing in particular with high interest rates. The notion of usury is not applied in contract law. The parallel in contract law to usury in criminal law is a provision on invalidity because of unfair exploitation. The provision is rarely applied nowadays.

Under the Late Payment Act, the interest rate in cases of late payment is fixed at eight percentage points above the Norwegian Central Bank's key policy rate, set every six months. The late payment interest rate currently (February 2014) stands at 9.75 per cent per year (no compound interest). ${ }^{*}{ }^{40}$ The rules are mandatory where the debtor is a consumer and the parties cannot validly agree to additional penalties etc. ${ }^{*} 4$ However, the ordinary contractual interest rate may still be claimed by the creditor. ${ }^{*}{ }^{2}$ For the loans we are dealing with here, the contractual interest rate will often be the higher one, not least because it will normally include compound interest. A claim for late payment interest may be reduced if the consumer had a good reason not to pay-for example, where the obligation to pay was contested. ${ }^{*} 43$ This rule is probably of scarce practical interest for loan contracts.

\section{Criminal law}

In criminal law, usury relates to unfair exploitation and not to the interest rate or other forms of remuneration. ${ }^{*} 44$ A provision on usury has not been included in the General Criminal Act 2005 (not yet in force); it was argued that the Price Measures Act (which also contains a penalty provision) was sufficient. ${ }^{*} 4$ In criminal law, cases on usury have also been rather rare, although, in a case from 2007, the Supreme Court pointed out that usury was obviously not of pure historical interest-the case dealt with blatant exploitation in criminal circles. ${ }^{*} 6$ The situation in that case was not at all similar, however, to the regular offering of fast loans to consumers dealt with here. It seems fair to say that rules on usury in criminal law are of little interest in this field.

\section{Conclusions}

Norway has, to date, been practically spared the consequences of the financial crisis. Aside from the future negative effects of international markets, there is currently more concern about growing household debt and a potential housing bubble. Instant loans make up just a small share of household debt. These loans still create serious problems, however, for a vulnerable group of consumers, as is shown by the role of such loans in consumer debt settlements.

Arguably, the most efficient consumer protection in this field lies in licence and supervision requirements, which apply to all providers of credit, and in the Consumer Ombudsman's control of marketing activities. The Financial Services Act regulates the relationship between lender and consumer, but the protection of the consumers' rights through contractual remedies has proved difficult, both because it is slow and costly and because courts and tribunals have been rather reluctant in their application of consumer protection legislation.

\footnotetext{
See, though, some interesting comments by General Advocate Wahl in Case C-26/13.

See the Supreme Court Judgment in Rt. 1969, 664 regarding law prior to the general clause.

Lov 100/1976 om renter ved forsinket betaling m.m. (Late Payment Act), Section 3(1).

Late Payment Act, Section 4.

Late Payment Act, Section 3(2).

Late Payment Act, Section 4(a); see for example, the Appeal Court decision in LB-2011-36899.

Almindelig borgerlig straffelov 22. mai 1902 nr. 10 (General Criminal Act), Section 295.

Ot.prp. nr. 22 (2008-2009) (the Government's proposal to the Parliament), p. 386.

Rt. 2007, p. 583.
} 